\title{
The incidence, risk, presentation, pathophysiology, treatment, and effects of perioperative acute kidney injury
}

\author{
Frederic T. Billings IV, MD, MSc (1) • Marcos G. Lopez, MD, MS • Andrew D. Shaw, MB
}

Received: 8 February 2019/Revised: 26 November 2019/Accepted: 13 October 2020/Published online: 6 January 2021

(C) Canadian Anesthesiologists' Society 2021

\begin{abstract}
Purpose Present clinical updates, current research findings, and consensus statements relevant to the care of the acute kidney injury (AKI) patient.

Principal findings Acute kidney injury is one of the most frequent and debilitating complications of surgery and critical illness. Consensus criteria use serum creatinine and urine output measurements to diagnose AKI and allow for objective diagnosis and more accurate comparisons across populations. New serum and urine biomarkers may provide earlier evidence of AKI, but their clinical utility, while increasing, remains limited. Avoidance of nephrotoxins, intravascular fluid management, and maintenance of renal perfusion are the mainstays of preventive management and treatment of AKI. Optimal timing for the initiation of renal replacement therapy is controversial and remains under investigation.

Conclusions Acute kidney injury continues to affect large numbers of patients receiving surgery or in the intensive care unit, but specific advances in resuscitation techniques, endpoint refinements, epidemiology, biomarkers, and pathology are providing the necessary framework to reduce AKI and associated morbidity.
\end{abstract}

F. T. Billings IV, MD, MSc ( $)$ · M. G. Lopez, MD, MS Department of Anesthesiology, Vanderbilt University Medical Center, 1161 21st Avenue South, T-4202, MCN, Nashville, TN 37232, USA

e-mail: frederic.t.billings@vumc.org

\section{A. D. Shaw, MB}

Department of Anesthesiology and Pain Medicine, University of Alberta, Edmonton, AB, Canada
Keywords acute kidney injury $\cdot$ AKI $\cdot$ perioperative . renal failure $\cdot$ dialysis $\cdot$ renal replacement therapy surgery

Mots-clés insuffisance rénale aiguë · IRA · périopératoire · insuffisance rénale $\cdot$ dialyse .

traitement substitutif de l'insuffisance rénale

Objectives of this Continuing Professional Development (CPD) module:

After reading this module, the reader should be able to:

1. Describe risk factors for the development of perioperative acute kidney injury (AKI)

2. Identify patients who meet consensus criteria for the diagnosis of AKI

3. Formulate treatment goals for reducing the risk of AKI

4. Describe the clinical management of patients with AKI who progress to renal failure

In the past decade, pre-clinical research has provided insight into the pathobiology of acute kidney injury (AKI) and into the associated cellular mechanisms of renal damage and repair. In addition, results from clinical trials and observational cohort studies have improved our capacity to accurately diagnose AKI, manage patients with AKI, and predict future events in patients with AKI. While effective preventive and therapeutic treatments for AKI are largely lacking, the clinical research framework to effectively test therapies has improved. In this report, we outline recent advances in the study of perioperative AKI. Among clinical updates, we present current research findings and consensus statements relevant to the care of the AKI patient. 


\section{Incidence and risk factors for $\mathrm{AKI}$}

Acute kidney injury is one of the most frequent and debilitating complications of surgery and critical illness. In the $21^{\text {st }}$ century, AKI affects $13 \%$ of patients receiving open abdominal surgery, $25 \%$ of patients receiving cardiac surgery, and $57 \%$ of patients admitted to an intensive care unit (ICU). ${ }^{1}$

The three most common precipitating events that lead to AKI are sepsis, surgery, and exposure to intravenous radiocontrast. The incidence of AKI is increased in patients with chronic kidney disease (CKD), diabetes, advanced age, African ancestry, chronic lung, liver, or cerebrovascular disease, and conditions that limit oxygen delivery to the kidneys including congestive heart failure, peripheral vascular disease, anemia, hypotension, venous congestion, and intravascular hypovolemia. It follows that anesthesiologists, intensivists, and surgeons must implement prevention strategies for AKI in patients with these risk factors who are exposed to sepsis, surgery, or radiocontrast.

\section{Pathophysiology of the development of AKI}

Perioperative AKI is primarily a result of renal malperfusion, oxidative damage, and inflammation. ${ }^{2}$ The cortico-medullary junction is relatively hypoxic $\left(\mathrm{PO}_{2}\right.$ $10-20 \mathrm{mmHg}$ ) in normal conditions, and during surgery and critical illness, systemic changes in cardiac output, systemic vascular resistance, and renal vein pressure alter cortical and medullary perfusion. At the same time, activation of the sympathetic nervous system, stimulation of the renin angiotensin aldosterone system, secretion of vasopressin, and release of endothelin- 1 further alter the renal microcirculation. Ischemia and reperfusion cycles induce reactive oxygen species (ROS) production from renal mitochondria. Reactive oxygen species impair endothelial function and perfusion homeostasis by eliminating nitric oxide, inciting pro-inflammatory transcription factors including nuclear factor-kappa B, and damaging surrounding tissues by oxidizing lipids, DNA, and additional proteins. Neutrophils and macrophages are recruited into the renal interstitium to regulate inflammation. The tubular epithelium loses polarity and its brush border. Necrotic and apoptotic cells are lost into the lumen, and myofibroblasts deposit collagen in the interstitium as the renal parenchyma becomes fibrotic. ${ }^{3}$ Septic AKI and radiocontrast-induced AKI, although unique in their presentation, are also products of altered microcirculation, oxidative damage, and renal inflammation.

\section{Clinical presentation of AKI-diagnosis}

Current consensus criteria for AKI diagnosis are based on measured changes in urine output and serum creatinine. The most current iteration-the Kidney Disease Improving Global Outcomes (KDIGO) criteria-defines stage 1 AKI as $\mathrm{a} \geq 26.5 \mu \mathrm{mol} \cdot \mathrm{L}^{-1}\left(0.3 \mathrm{mg} \cdot \mathrm{dL}^{-1}\right)$ serum creatinine increase from baseline within $48 \mathrm{hr}$ of surgery, a $50 \%$ serum creatinine increase from baseline within seven days of surgery, or urine output below $0.5 \mathrm{~mL} \cdot \mathrm{kg}^{-1} \cdot \mathrm{hr}^{-1}$ for six hours. The KDIGO criteria define stage 2 AKI as a $100 \%$ serum creatinine increase within seven days of surgery or urine output below $0.5 \mathrm{~mL} \cdot \mathrm{kg}^{-1} \cdot \mathrm{hr}^{-1}$ for $12 \mathrm{hr}$, and stage 3 AKI as a $200 \%$ increase in serum creatinine within seven days of surgery or urine output below $0.3 \mathrm{~mL} \cdot \mathrm{kg}^{-1} \cdot \mathrm{hr}^{-1}$ for $24 \mathrm{hr}$ or anuria for $12 \mathrm{hr}$ (Table 1). ${ }^{4}$ The use of consensus criteria enables clinicians to objectively identify AKI, to compare AKI rates across providers, institutions, and patient populations, and to establish endpoints for therapeutic and prophylactic treatment trials. Unfortunately, changes in serum creatinine concentration often lack sensitivity and specificity for renal injury because the association between renal injury and serum creatinine is often confounded by changes in creatinine production, myocyte injury, intravenous fluid administration, intravascular fluid extravasation, diuretic use, tubular creatinine secretion, and renal functional reserve. Early changes in serum creatinine reflect the impact of hemorrhage, resuscitation, and hemodilution as much as they do renal function and injury. Urine output is also non-specific for AKI and may lead to an overdiagnosis of AKI. Nonetheless, patients that meet AKI criteria by both an increase in serum creatinine and a decrease in urine output have significantly worse long-term renal outcomes and mortality than patients that only meet serum creatinine or urine output criteria. ${ }^{5}$

Biomarkers of renal injury that are expressed in the urine or plasma within hours of renal injury have been identified, and these markers may be more specific and sensitive for renal stress and injury than markers of impaired glomerular filtration (Table 2). ${ }^{6,7}$ Their clinical use for diagnosis and management of AKI, however, remains limited. In fact, most of these markers remain confined to research purposes. The US Food and Drug Administration has approved the measurement of urinary tissue inhibitor of metalloproteinases-2 and insulin-like growth factor binding protein 7 (TIMP-2-IGFBP7), markers of growth phase cell-cycle arrest, to aid in the risk assessment for moderate or severe AKI within $12 \mathrm{hr}$ of cardiac surgery, thus providing a commercially available test to measure kidney stress. The validation of TIMP2.IGFBP7 for acute and persistent renal injury in different clinical settings is ongoing. 
TABLE 1 Kidney disease improving global outcomes (KDIGO) consensus criteria for acute kidney injury (AKI)

\begin{tabular}{lll}
\hline AKI stage & Serum creatinine concentration & Urine output \\
\hline 1 & $50-100 \%$ increase within 7 days or & $<0.5 \mathrm{~mL} \cdot \mathrm{kg}^{-1} \cdot \mathrm{hr}^{-1}$ or $6-12 \mathrm{hr}$ \\
& $\geq 26.5 \mu \mathrm{mol} \cdot \mathrm{L}^{-1}\left(0.3 \mathrm{mg} \cdot \mathrm{dL}^{-1}\right)$ increase within $48 \mathrm{hr}$ & \\
2 & $100-200 \%$ increase within 7 days & $<0.5 \mathrm{~mL} \cdot \mathrm{kg}^{-1} \cdot \mathrm{hr}^{-1} \mathrm{for}>12 \mathrm{hr}$ \\
3 & $\geq 200$ increase, $\geq 354 \mu \mathrm{mol} \cdot \mathrm{L}^{-1}(4.0 \mathrm{mg} / \mathrm{dl})$ with a $\geq 44 \mu \mathrm{mol} \cdot \mathrm{L}^{-1}$ & $<0.3 \mathrm{~mL} \cdot \mathrm{kg}^{-1} \cdot \mathrm{hr}^{-1}$ for $\geq 24 \mathrm{hr}$ or anuria for $\geq 12 \mathrm{hr}$ \\
& $\left(0.5 \mathrm{mg} \cdot \mathrm{dL}^{-1}\right)$ increase, or dialysis within 7 days & \\
\hline
\end{tabular}

TABLE 2 Features and utility of markers of acute kidney injury (AKI). Data represent approximations since these features of AKI depend on severity and persistence of injury. $\star=$ Least relevant or favourable; $\star \star \star \star \star=$ Most relevant or favourable; NA $=$ not applicable

\begin{tabular}{|c|c|c|c|c|c|c|c|c|}
\hline Feature & $\begin{array}{l}\text { Functional } \\
\text { marker }\end{array}$ & $\begin{array}{l}\text { Damage } \\
\text { marker }\end{array}$ & $\begin{array}{l}\text { Time of } \\
\text { onset }\end{array}$ & $\begin{array}{l}\text { Time of peak } \\
\text { expression }\end{array}$ & $\begin{array}{l}\text { AUROC } v s \\
\text { KDIGO }\end{array}$ & $\begin{array}{l}\text { Marker of } \\
\text { prognosis }\end{array}$ & $\begin{array}{l}\text { Clinical } \\
\text { availability }\end{array}$ & $\begin{array}{l}\text { Favourable } \\
\text { cost }\end{array}$ \\
\hline Urine output & $\star \star$ & $\star$ & $1 \mathrm{hr}$ & $24 \mathrm{hr}$ & 1.00 & $\star$ & $\star \star \star \star$ & $\star \star \star \star \star ~$ \\
\hline Serum creatinine & $\star \star \star$ & $\star \star$ & $24 \mathrm{hr}$ & $72 \mathrm{hr}$ & 1.00 & $\star$ & $\star \star \star \star \star$ & $\star \star \star \star$ \\
\hline Serum cystatin C & $\star \star \star \star$ & $\star \star$ & $24 \mathrm{hr}$ & $72 \mathrm{hr}$ & 0.63 & $\star$ & $\star$ & $\star$ \\
\hline Urine NGAL & $\star$ & $\star \star \star \star$ & $2 \mathrm{hr}$ & $6 \mathrm{hr}$ & 0.70 & $\star \star$ & $\star$ & $\star$ \\
\hline Urine KIM-1 & $\star$ & $\star \star \star \star$ & $6 \mathrm{hr}$ & $24 \mathrm{hr}$ & 0.68 & $\star \star$ & $\star$ & $\star$ \\
\hline $\begin{array}{l}\text { Urine IGFBP7 } \\
\text { TIMP-2 }\end{array}$ & $\star$ & $\star \star \star \star$ & $1 \mathrm{hr}$ & $6 \mathrm{hr}$ & 0.75 & $\star \star$ & $\star \star \star$ & $\star \star$ \\
\hline Dialysis & $\star \star \star \star$ & $\star \star$ & $36 \mathrm{hr}$ & NA & 1.00 & $\star \star \star \star$ & 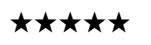 & $\star \star \star \star \star$ \\
\hline MAKE 30 & $\star \star \star \star$ & $\star \star$ & 30 days & NA & NA & $\star \star \star$ & $\star \star \star \star$ & $\star \star \star \star$ \\
\hline MAKE 90 & $\star \star \star \star \star$ & $\star \star$ & 90 days & NA & NA & $\star \star \star \star$ & $\star \star \star \star \star$ & $\star \star \star \star$ \\
\hline
\end{tabular}

AUROC $=$ area under the receiver operating characteristic curve-range $0.00-1.00$ where a higher value indicates superior association with KDIGO AKI criteria; KDIGO = kidney disease improving global outcomes; NGAL = neutrophil gelatinase-associated lipocalin; KIM-1 = kidney injury molecule 1; IGFBP7 = insulin-like growth factor binding protein 7; TIMP-2 = tissue inhibitor of metalloproteinase 2; MAKE = major adverse kidney events, a dichotomous endpoint at 30 or 90 days defined as a $25 \%$ estimated glomerular filtration rate decline, new dialysis, or death.

\section{Prevention of AKI}

Intravascular fluid management remains a mainstay of AKI prevention. The best composition of isotonic fluid has until recently remained unclear. In critically ill patients, a balanced salt solution that approximates plasma concentrations of sodium, chloride, and potassium, such as Plasma-Lyte, Hartman's solution, or lactated Ringer's solution has been associated with less major adverse kidney events (MAKE) at 30 days compared with hyperchloremic solutions such as "normal" (0.9\%) saline, ${ }^{8}$ and recent evidence suggests that balanced isotonic salt solutions may protect the kidneys compared with isotonic sodium chloride. The SMART trial, a large randomized trial of balanced salt solution or saline treatment immediately upon presentation to the ICU, found that a balanced salt solution reduces MAKE30 compared with saline. ${ }^{9}$ Therefore, aside from select patient populations such as those with increased intracranial pressure, a balanced salt solution may be preferable treatment in acutely ill patients. Recovery pathways that promote restrictive administration of intravenous fluids with a goal of advancing early recovery in patients undergoing major surgery have become popular despite limited evidence. The RELIEF trial, however, randomized 3,000 major abdominal surgery patients to restrictive (approximately $1.5 \mathrm{~L}$ of balanced crystalloid solution during a four-hour surgery followed by $0.8 \mathrm{~mL} \cdot \mathrm{kg}^{-1} \cdot \mathrm{hr}^{-1}$ for at least $24 \mathrm{hr}$ postoperatively) or liberal (approximately $3 \mathrm{~L}$ of balanced crystalloid during a four hour surgery followed by $1.5 \mathrm{~mL} \cdot \mathrm{kg}^{-1} \cdot \mathrm{hr}^{-1}$ for at least $24 \mathrm{hr}$ postoperatively) intravenous fluid administration during surgery and in the early postoperative period and found that restrictive fluid administration was not associated with disability-free survival. $^{10}$ In addition, pre-specified secondary analyses noted increased AKI in the restrictive administration group compared with the liberal administration group. Additional large pragmatic randomized clinical trials (RCTs), including PLUS (NCT02721654), BaSICS (NCT02875873), and SOLAR 
(NCT02565420) will provide more evidence on the relative renal benefits and harms of commonly administered crystalloid intravenous fluids.

Radiocontrast-associated AKI may also be affected by choice of resuscitative crystalloid fluid. For example, administration of intravenous isotonic fluid decreases AKI when compared with hypotonic fluid in patients receiving intravenous radiocontrast. Based on the rationale that sodium bicarbonate may reduce oxidative stress in the nephron or in the blood by scavenging ROS and by decreasing ROS generated via iron-dependent mechanisms, clinician scientists have hypothesized that administration of sodium bicarbonate decreases radiocontrast-induced AKI. Recent trials in patients exposed to radiocontrast, however, found no difference in rates or severity of contrast-induced AKI or persistent renal injury between patients administered isotonic sodium bicarbonate and patients administered isotonic sodium chloride. ${ }^{11}$

Colloid solutions have been the subject of many investigations examining their effect on kidney injury and renal recovery. Using the rationale that increased colloid oncotic pressure might limit intravascular fluid extravasation, starch solutions were historically administered as part of intravascular volume resuscitation. Some hydroxylethyl starch solutions have been noted to increase the risk of AKI and renal replacement therapy (RRT) and lead to increased mortality in septic patients. ${ }^{12}$ Data regarding the use of albumin as a resuscitative solution are inconclusive. In septic patients, no effect of albumin resuscitation on AKI or need for RRT has been noted in large meta-analyses. ${ }^{13}$ In a study of hypoalbuminemic patients undergoing off pump coronary artery bypass surgery, administration of $20 \%$ albumin preoperatively increased urine output and decreased the risk of AKI. ${ }^{14}$ The administration of albumin is more costly than administration of crystalloid solutions, and results of trials examining the effects of albumin on AKI are mixed. There may be some benefit to its administration in hypoalbuminemic patients, but there is insufficient evidence to support widespread use of albumin as a resuscitative fluid to prevent AKI.

Anemia can decrease renal oxygen delivery, and a hemoglobin concentration less than $8 \mathrm{~g} \cdot \mathrm{dL}^{-1}\left(5 \mathrm{mmol} \cdot \mathrm{L}^{-1}\right)$ during noncardiac surgery is associated with a $400 \%$ increase in AKI. ${ }^{15}$ Transfusion with packed red blood cells, however, has also been associated with AKI. ${ }^{16}$ The TRICS III trial randomized 4,860 cardiac surgery patients to a transfusion threshold of $9.5 \mathrm{~g} \cdot \mathrm{dL}^{-1}$ or $7.5 \mathrm{~g} \cdot \mathrm{dL}^{-1}$. Transfusion threshold did not affect new renal failure requiring dialysis, despite increased transfusion in the higher threshold group, and a kidney substudy of this trial noted no differences in mild, moderate, or severe AKI between randomized treatment groups. ${ }^{17}$ Transfusion of packed red blood cells stored longer prior to transfusion also increases the risk of AKI. Putative mechanisms include increased inflammation, oxidative stress, or impaired oxygen delivery. Current recommendations emphasize prevention of anemia and judicious blood product transfusion in surgical patients at risk for AKI to balance the risks of anemia and transfusion.

Preventive management for AKI also includes maintenance of renal perfusion and the avoidance of medications that decrease glomerular filtration in patients that are hypovolemic, such as non-steroidal antiinflammatory drugs and angiotensin converting enzyme inhibitors, and avoidance of nephrotoxins, including intravenous radiocontrast and aminoglycosides. Identifying patients who are hypovolemic and quantifying the degree of intravascular depletion remains a significant clinical problem, particularly since excess resuscitation and hypervolemia lead to venous congestion, a condition associated with AKI in cohorts of patients receiving surgery, with sepsis, admitted to the ICU, and with heart failure. ${ }^{18}$ No longer can clinicians feel they are protecting the kidneys by administering large amounts of intravenous fluids. Clinicians should maintain renal perfusion by preserving or augmenting cardiac output, by treating hypotension with agents that also increase cardiac output or with intravenous fluids while avoiding hypervolemia, and by avoiding severe anemia. Vasoactive agents used to treat hypotension that exclusively increase systemic vascular resistance, such as phenylephrine, may not best preserve renal perfusion. In an RCT of patients with vasoplegic shock after cardiac surgery who received norepinephrine, however, patients treated with vasopressin were less likely to develop a composite endpoint of mortality or organ dysfunction compared with patients treated with additional norepinephrine. Vasopressin-treated patients had a hazard ratio of 0.26 for renal failure compared with norepinephrine-treated patients, and additional trials examining vasopressin should be performed. ${ }^{19}$

Even though renal ischemia is responsible for a large portion of perioperative AKI, treatments to augment renal perfusion or decrease renal oxygen consumption, including the administration of dopamine receptor agonists or diuretics, have largely failed. Dopamine agonists increase renal perfusion, glomerular filtration, sodium delivery to the tubule, solute reabsorption requirements, and renal tubule oxygen consumption. Diuretics decrease renal oxygen consumption but can lead to hypovolemia and do not decrease AKI. Other preventive therapies, including perioperative administration of statins in patients having cardiac surgery, sodium bicarbonate, ${ }^{20}$ corticosteroids, $^{21}$ and alkaline phosphatase have yielded mixed results but generally failed to reduce AKI. Similarly, multiple clinical 
trials examining perioperative administration of antioxidants such as $\mathrm{N}$-acetylcysteine or mannitol do not support their routine administration to prevent AKI. Remote ischemic preconditioning is performed by inflating a cuff on a limb (most commonly the arm) to suprasystolic pressure for three cycles of five minutes. In cardiac surgery patients, two large RCTs have found that remote ischemic preconditioning does not decrease risk of AKI while another has observed a protective effect against AKI.

\section{Acute kidney injury progression, management, and prognosis}

Until specific therapeutics are available, AKI treatment must focus on supportive care and avoiding further insults. While numerous modifiable risk factors such as anemia, hypotension, impaired cardiac output, hemolysis, rhabdomyolysis, exposure to nephrotoxic drugs, and blood transfusion have been identified, most pharmacologic prevention (and salvage) treatment strategies have failed to reverse surgical AKI or limit its progression. $^{22}$ Goal-directed hemodynamic management is a reasonable approach as it uses protocolized monitoring and interventions with pre-specified hemodynamic targets. Broadly speaking, this patient management strategy has also failed to consistently limit AKI, although a study in cardiac surgery patients showed that stroke volume optimization-achieved by monitoring the effects of 250 $\mathrm{mL}$ fluid challenges on left ventricle stroke volumereduced the incidence of AKI from $19.9 \%$ to $6.5 \%(P=$ $0.002) .^{23}$

Acidosis, electrolyte derangements, intravascular volume overload, and severe uremia typically herald the onset of AKI that requires RRT. It is unclear if early or late initiation of RRT reverses critical illness, improves survival, or improves long-term kidney function. Three recent randomized clinical trials have addressed this question. Zarbock et al. found evidence that initiation of RRT within eight hours of stage 2 AKI reduces 90-day mortality, duration of RRT, duration of mechanical ventilation, and duration of hospitalization, and increases recovery of renal function compared with initiation of RRT within $12 \mathrm{hr}$ of stage $3 \mathrm{AKI}$ in 231 critically ill patients (ELAIN trial). ${ }^{24}$ At one year follow up, decreased MAKE and mortality and enhanced renal recovery persisted in ELAIN trial patients who received early RRT. Gaudry et al., however, found that patients with stage $3 \mathrm{AKI}$ assigned immediate RRT had similar 60-day mortality to patients assigned RRT after development of significant renal failure sequelae and experienced increased catheterrelated blood stream infections and delayed return of renal function (AKIKI trial). ${ }^{25}$ Barbar et al. randomized 488 patients with early-stage septic shock and renal failure, defined by RIFLE criteria, to RRT at $12 \mathrm{hr}$ after documented renal failure or at $48 \mathrm{hr}$ if renal recovery had not occurred (IDEAL-ICU trial). ${ }^{26}$ This trial was stopped early for futility, with no significant difference in the primary outcome of death at 90 days between groups. Importantly, the ELAIN trial included mostly surgical patients with a high prevalence of fluid overload, while the AKIKI and IDEAL-ICU trials included mostly medical patients with a high prevalence of sepsis. Perhaps the initiation of RRT while patients were still in moderate AKI led to an early RRT treatment benefit in the ELAIN trial. The STARRT-AKI trial (NCT02568722) aims to enroll and randomize 2,866 patients with stage 2 AKI or specific clinical criteria to early or late RRT and will provide more evidence. Thus, at present it remains unclear if initiation of RRT in patients with moderate AKI salvages the kidneys compared with waiting until patients recover or develop more severe AKI.

A "furosemide stress test" is the administration of furosemide to a patient who has oliguria or AKI to better predict the progression of AKI and the need for subsequent RRT. It is based on a study that showed that the volume of urine output following a $1-1.5 \mathrm{mg} \cdot \mathrm{kg}^{-1}$ dose of intravenous furosemide produced a C-statistic of 0.82 and 0.87 to predict development of stage $3 \mathrm{AKI}$ in two cohorts of patients with stage 1 or $2 \mathrm{AKI}^{27}$ A urine output less than $200 \mathrm{~mL}$ in the two hours following furosemide administration had $87.1 \%$ sensitivity and $84.1 \%$ specificity to predict progression to stage 3 AKI. The authors of this study caution that urine output should be replaced with intravenous fluids during a furosemide stress test unless the patient is frankly intravascularly overloaded, as numerous studies have shown that the administration of furosemide to reverse oliguria does not reduce but increases AKI. Outside of a furosemide stress test, furosemide should be reserved to treat intravascular hypervolemia.

Hospital mortality for AKI patients who require dialysis remains a staggering $30 \% .^{1}$ Renal failure is frequently accompanied by respiratory failure, arrhythmias, cardiovascular failure, severe infections, polyneuropathy, weakness, and delirium. ${ }^{28}$ There is increasing evidence that these organ injuries do not just occur simultaneously in response to a common insult, but that impaired fluid and electrolyte homeostasis, reduced waste (fixed acids and urea) elimination, renal cytokine production, decreased cytokine clearance, neurohormonal signalling pathways, or impaired neutrophil activity cause deleterious effects to extra-renal organs. For example, pre-clinical experimental renal ischemia-reperfusion precipitates neutrophil margination in the contralateral kidney, spleen, and 
FIGURE 1 Renal function trajectories in patients who do and do not suffer acute kidney injury (AKI) and do and do not progress to chronic kidney disease (CKD).Trajectoires de fonction rénale chez les patients qui souffrent et ne souffrent pas d'insuffisance rénale aiguë (IRA) et évoluent ou non vers une insuffisance rénale chronique (IRC).

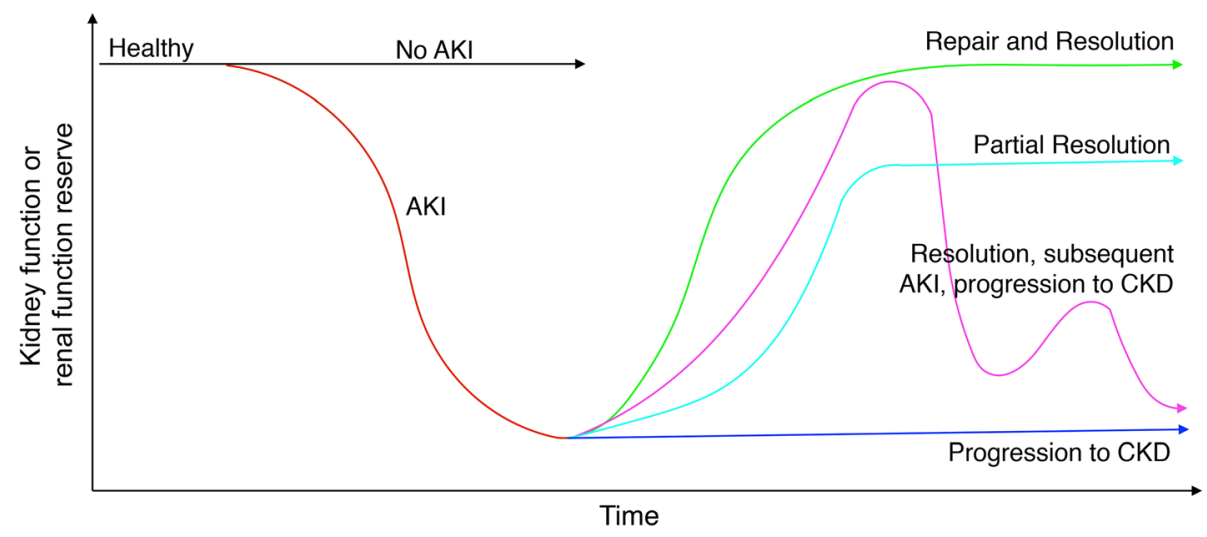

lungs, ${ }^{29}$ and macrophage infiltration in lung and myocardial interstitium, ${ }^{30}$ and causes lung and brain edema. These extra-renal effects of experimental AKI may explain the clinical observations that even stage $1 \mathrm{AKI}$ increases the risk of extra-renal organ failure and is associated with a seven-fold increase in 30-day mortality.

\section{Resolution of AKI-short- and long-term effects}

The kidneys can recover from AKI. After tubular cell loss, surviving cells, stimulated by paracrine signalling from bone marrow-derived progenitor cells, dedifferentiate, proliferate, migrate along the basement membrane, and differentiate into mature tubule cells, replenishing the tubular epithelium. ${ }^{3}$ This process, however, is frequently maladaptive. The severity of AKI and repetitive AKI events increase risk of CKD progression (Figure 1). Even if renal function recovers following $\mathrm{AKI}$, patients that suffer AKI are at increased risk for developing subsequent episodes of AKI or worsening CKD.

Acute kidney injury is a common, complicated, and dreadful complication of acute illness. Patients often recover from AKI but suffer subsequent morbidity. Our understanding of the pathophysiology of AKI development, however, has improved, and recent empiric treatments have emerged. Future work will focus on prophylactic therapy for AKI and extending patient monitoring and treatment after AKI resolution.

\section{Clinical case scenario}

Ms. Henle, a 68-yr-old woman, presented to the emergency department with a fever and a cold swollen left foot. She has a history of hyperlipidemia and congestive heart failure. Her heart rate is 93 beats. $\min ^{-1}$ and blood pressure $95 / 50 \mathrm{mmHg}$. Her left foot is mottled, and distal pulses are diminished. Her serum creatinine measures $124 \mu \mathrm{mol} \cdot \mathrm{L}^{-1}$ $\left(1.4 \mathrm{mg} \cdot \mathrm{dL}^{-1}\right)$. She is urgently taken for angiography and embolectomy under monitored anesthesia care. She receives a Foley catheter to monitor urine output. She receives $1.5 \mathrm{~L}$ of intravenous Ringer's lactate solution, several phenylephrine boluses to treat hypotension, and $125 \mathrm{~mL}$ of radiocontrast during left popliteal artery dilation and stenting. In the postanesthesia care unit, her heart rate is 115 beats $\cdot \mathrm{min}^{-1}$ and blood pressure $82 / 42 \mathrm{mmHg}$. Serum potassium measures $5.4 \mathrm{mEq} \cdot \mathrm{L}^{-1}$. She is somnolent and anuric. Her resident physician orders a $500 \mathrm{~mL}$ bolus of intravenous $0.9 \%$ saline, concerned that administration of a balanced fluid containing potassium could worsen her hyperkalemia, and a phenylephrine infusion. She is transferred to the intensive care unit for further treatment.

Instructions for completing the continuing professional development (CPD) module:

1. Read the current article and the four references indicated in bold (references ${ }^{1,2,22,28}$ ).

2. Go to: http://www.cas.ca/Members/CPD-Online and select the current module (The incidence, risk, presentation, pathophysiology, treatment, and effects of perioperative acute kidney injury).

3. Answer the multiple-choice questions regarding the case scenario.

4. Once you have entered your answers, you will have access to experts' explanations for all the possible choices.

5. Participants may claim up to four hours of CPD under Section 3 of the CPD program of the Royal College of Physicians and Surgeons of Canada. 


\section{L'insuffisance rénale aiguë périopératoire: incidence, risques, présentation, physiopathologie, traitement et conséquences}

\section{Résumé}

Objectif Présenter les mises à jour cliniques, les résultats de recherche actuels et les énoncés de consensus pertinents concernant les soins des patients atteints d'insuffisance rénale aiguë (IRA).

Constatations principales L'insuffisance rénale aiguë est l'une des complications les plus fréquentes et débilitantes de la chirurgie et des maladies critiques. Les critères consensuels se fondent sur des mesures de la créatininémie et de la diurèse pour diagnostiquer l'IRA et favorisent un diagnostic objectif et des comparaisons plus précises entre les populations. Les nouveaux biomarqueurs sériques et urinaires pourraient permettre une identification précoce de l'IRA mais leur utilité clinique, certes croissante, demeure limitée. Les piliers d'une prise en charge et d'un traitement préventif de l'IRA demeurent la minimisation de l'exposition aux néphrotoxines, la gestion liquidienne intravasculaire et le maintien de la perfusion rénale. Le moment optimal pour l'amorce d'un traitement substitutif de l'insuffisance rénale demeure controversé et reste à déterminer.

Conclusion L'insuffisance rénale aiguë continue d'affecter un grand nombre de patients recevant une chirurgie ou à l'unité de soins intensifs, mais des progrès spécifiques dans les techniques de réanimation, les indicateurs de résultat, dans l'épidémiologie, les biomarqueurs et la pathologie fournissent le cadre nécessaire pour réduire l'IRA et la morbidité associée.

\section{Objectifs de ce module de Développement professionnel continu (DPC):}

Après avoir lu ce module, le lecteur devrait être en mesure de :

1. Décrire les facteurs de risque de développer une insuffisance rénale aiguë (IRA) périopératoire

2. Identifier les patients qui répondent aux critères consensuels de diagnostic de l'IRA

3. Formuler des objectifs de traitement pour réduire le risque d'IRA
4. Décrire la prise en charge clinique des patients atteints d'IRA évoluant vers l'insuffisance rénale

$\mathrm{Au}$ cours de la dernière décennie, la recherche préclinique a permis de mieux comprendre la pathobiologie de l'insuffisance rénale aiguë (IRA) et les mécanismes cellulaires associés aux lésions rénales et à leur réparation. En outre, les résultats des essais cliniques et des études de cohorte observationnelles ont amélioré notre capacité à diagnostiquer avec précision l'IRA, à prendre en charge les patients atteints d'IRA et à prédire les complications chez les patients atteints d'IRA. Bien que les traitements préventifs et thérapeutiques efficaces pour l'IRA soient quasi inexistants, le cadre de recherche clinique permettant de tester efficacement les thérapies s'est amélioré. Dans ce compte rendu, nous présentons les progrès récents dans l'étude de l'IRA périopératoire. Parmi les mises à jour cliniques, nous présentons les résultats de recherche et les énoncés de consensus actuels pertinents pour les soins des patients atteints d'IRA.

\section{Incidence et facteurs de risque d'IRA}

L'insuffisance rénale aiguë est l'une des complications les plus fréquentes et débilitantes de la chirurgie et des maladies critiques. Au $21^{\mathrm{e}}$ siècle, l'IRA touche $13 \%$ des patients subissant une chirurgie abdominale ouverte, $25 \%$ des patients subissant une chirurgie cardiaque et $57 \%$ des patients admis dans une unité de soins intensifs (USI). ${ }^{1}$

Les trois événements déclencheurs les plus courants qui entraînent une IRA sont le sepsis, la chirurgie, et l'exposition aux produits de contraste intraveineux. L'incidence d'IRA est plus importante chez les patients atteints d'insuffisance rénale chronique (IRC), de diabète, d'âge avancé, d'ascendance africaine, de maladie pulmonaire, hépatique ou cérébrovasculaire chronique, et chez les patients atteints de conditions qui limitent l'oxygénation des reins, notamment l'insuffisance cardiaque congestive, les maladies vasculaires périphériques, l'anémie, l'hypotension, la congestion veineuse, et l'hypovolémie intravasculaire. Il s'ensuit que les anesthésiologistes, les intensivistes et les chirurgiens doivent mettre en œuvre des stratégies de prévention de l'IRA chez les patients présentant ces facteurs de risque qui sont exposés au sepsis, à la chirurgie ou aux produits de contraste.

\section{Physiopathologie de l'évolution de l'IRA}

L'IRA périopératoire est en grande partie due à une malperfusion rénale, aux lésions oxydatives, et à 
l'inflammation. ${ }^{2}$ Dans des conditions normales, la jonction cortico-médullaire est relativement hypoxique $\left(\mathrm{PO}_{2} \quad 10-20\right.$ $\mathrm{mmHg}$ ); pendant une chirurgie et en cas de maladie critique, les changements systémiques du débit cardiaque, de la résistance vasculaire systémique et de la pression veineuse rénale altèrent les perfusions corticale et médullaire. En même temps, l'activation du système nerveux sympathique, la stimulation du système rénineangiotensine-aldostérone, la sécrétion de vasopressine, et la libération d'endothéline-1 modifient encore plus la microcirculation rénale. Les cycles d'ischémie et de reperfusion induisent la production d'espèces réactives de l'oxygène (ERO) à partir de mitochondries rénales. Les espèces réactives de l'oxygène dégradent la fonction endothéliale et l'homéostasie de perfusion en éliminant le monoxyde d'azote (NO), produisant des facteurs de transcription pro-inflammatoires, notamment le facteur nucléaire kappa $\mathrm{B}$, et endommageant les tissus environnants en oxydant les lipides, l'ADN, et d'autres protéines. Les neutrophiles et les macrophages sont recrutés dans le tissu interstitiel rénal pour réguler l'inflammation. L'épithélium tubulaire perd sa polarité et sa bordure en brosse. Les cellules nécrotiques et apoptotiques se retrouvent dans la lumière rénale, et les myofibroblastes déposent du collagène dans l'interstitium pendant que le parenchyme rénal devient fibrotique. ${ }^{3}$ Bien qu'elles se distinguent dans leur présentation, l'IRA septique et l'IRA induite par les produits de contraste sont également les résultats d'une microcirculation altérée, de lésions oxydatives et d'une inflammation rénale.

\section{Présentation clinique de l'IRA - diagnostic}

Les critères de consensus actuels pour le diagnostic de l'IRA se fondent sur des changements mesurés dans la diurèse et la créatininémie. Les critères consensuels les plus récents sont les critères KDIGO (Kidney Disease Improving Global Outcomes), qui définissent l'IRA de stade 1 en tant qu'une augmentation de la créatininémie de $\geq 26,5 \mu \mathrm{mol} \cdot \mathrm{L}^{-1}\left(0,3 \mathrm{mg} \cdot \mathrm{dL}^{-1}\right)$ par rapport à sa valeur de base dans les 48 heures suivant la chirurgie, une augmentation de $50 \%$ de la créatininémie par rapport à sa valeur de base dans les sept jours suivant la chirurgie, ou une diurèse inférieure à $0,5 \mathrm{~mL} \cdot \mathrm{kg}^{-1} \cdot \mathrm{h}^{-1}$ pendant six heures. Les critères KDIGO définissent l'IRA de stade 2 comme une augmentation de $100 \%$ de la créatininémie dans les sept jours suivant la chirurgie ou une diurèse inférieure à $0,5 \mathrm{~mL} \cdot \mathrm{kg}^{-1} \cdot \mathrm{h}^{-1}$ pendant 12 heures, et l'IRA de stade 3 comme une augmentation de $200 \%$ de la créatininémie dans les sept jours suivant la chirurgie, ou une diurèse inférieure à $0,3 \mathrm{~mL} \cdot \mathrm{kg}^{-1} \cdot \mathrm{h}^{-1}$ pendant 24 heures ou anurie pendant 12 heures (tableau 1). ${ }^{4}$ L'utilisation de critères consensuels permet aux cliniciens d'identifier objectivement l'IRA, de comparer les taux d'IRA entre les fournisseurs de soins, les institutions et les populations de patients, et d'établir des critères d'évaluation pour les études thérapeutiques et prophylactiques. Malheureusement, les changements dans la concentration de créatininémie manquent souvent de sensibilité et de spécificité pour les lésions rénales parce que l'association entre les lésions rénales et la créatininémie est souvent faussée par des changements dans la production de créatinine, les lésions myocytaires, l'administration intraveineuse de liquides, l'extravasation intravasculaire liquidienne, l'utilisation de diurétiques, la sécrétion tubulaire de créatinine, et la réserve fonctionnelle rénale. Les changements précoces dans la créatininémie reflètent l'impact de l'hémorragie, de la réanimation, et de l'hémodilution autant que de la fonction et des lésions rénales. La diurèse est également non spécifique à l'IRA et pourrait entraîner un surdiagnostic de l'IRA. Cependant, les patients répondant aux critères d'IRA par une augmentation de la créatininémie et une diminution de la diurèse présentent des pronostics rénaux et une mortalité significativement plus graves à long terme que les patients ne répondant qu'au critère de créatininémie ou de diurèse. ${ }^{5}$

Certains biomarqueurs de lésion rénale retrouvés dans l'urine ou le plasma dans les heures suivant la lésion rénale ont été identifiés, et ces marqueurs pourraient être plus spécifiques et sensibles pour identifier le stress et les lésions rénaux que les marqueurs d'une filtration

TABLEAU 1 Critères consensuels KDIGO (Kidney Disease Improving Global Outcomes) pour l'insuffisance rénale aiguë (IRA)

\begin{tabular}{lll}
\hline Stade de l'IRA & Concentration de créatinine sérique & Diurèse \\
\hline 1 & augmentation de 50 à $100 \%$ dans les 7 jours ou & $<0,5 \mathrm{~mL} \cdot \mathrm{kg}^{-1} \cdot \mathrm{h}^{-1} \mathrm{ou} 6 \mathrm{à} 12 \mathrm{~h}$ \\
& augmentation de $\geq 26,5 \mu \mathrm{mol} \cdot \mathrm{L}^{-1}\left(0,3 \mathrm{mg} \cdot \mathrm{dL}^{-1}\right)$ dans les 48 heures & $<0,5 \mathrm{~mL} \cdot \mathrm{kg}^{-1} \cdot \mathrm{h}^{-1} \mathrm{pendant}>12 \mathrm{~h}$ \\
2 & augmentation de 100 à $200 \%$ dans les 7 jours ou & $<0,3 \mathrm{~mL} \cdot \mathrm{kg}^{-1} \cdot \mathrm{h}^{-1} \mathrm{pendant} \geq 24 \mathrm{~h} \mathrm{ou}$ \\
3 & $\begin{array}{l}\text { augmentation } \geq 200, \geq 354 \mu \mathrm{mol} \cdot \mathrm{L}^{-1}(4,0 \mathrm{mg} / \mathrm{dL}) \text { avec une } \\
\text { augmentation de } \geq 44 \mu \mathrm{mol} \cdot \mathrm{L}^{-1}\left(0,5 \mathrm{mg} \cdot \mathrm{dL}^{-1}\right), \text { ou dialyse dans les }\end{array}$ &
\end{tabular}


TABLEAU 2 Caractéristiques et utilité des marqueurs de l'insuffisance rénale aiguë (IRA). Les données représentent des approximations puisque ces caractéristiques de l'IRA dépendent de la gravité et de la persistance de la lésion. $\star=$ Le moins pertinent ou favorable; $\star \star \star \star \star=$ Le plus pertinent ou favorable; NA $=$ non applicable.

\begin{tabular}{|c|c|c|c|c|c|c|c|c|}
\hline Caractéristique & $\begin{array}{l}\text { Marqueur } \\
\text { fonctionnel }\end{array}$ & $\begin{array}{l}\text { Marqueur } \\
\text { de lésion }\end{array}$ & $\begin{array}{l}\text { Moment } \\
\text { du début }\end{array}$ & $\begin{array}{l}\text { Moment de } \\
\text { l'expression } \\
\text { maximale }\end{array}$ & $\begin{array}{l}\text { ASC-ROC } v s \\
\text { KDIGO }\end{array}$ & $\begin{array}{l}\text { Marqueur de } \\
\text { pronostic }\end{array}$ & $\begin{array}{l}\text { Disponibilité } \\
\text { clinique }\end{array}$ & $\begin{array}{l}\text { Coût } \\
\text { favorable }\end{array}$ \\
\hline Diurèse & $\star \star$ & $\star$ & $1 \mathrm{~h}$ & $24 \mathrm{~h}$ & 1,00 & $\star$ & $\star \star \star \star$ & $\star \star \star \star \star \star$ \\
\hline Créatininémie & $\star \star \star$ & $\star \star$ & $24 \mathrm{~h}$ & $72 \mathrm{~h}$ & 1,00 & $\star$ & $\star \star \star \star \star$ & $\star \star \star \star$ \\
\hline $\begin{array}{l}\text { Cystatine C } \\
\text { sérique }\end{array}$ & $\star \star \star \star$ & $\star \star$ & $24 \mathrm{~h}$ & $72 \mathrm{~h}$ & 0,63 & $\star$ & $\star$ & $\star$ \\
\hline NGAL dans l'urine & $\star$ & $\star \star \star \star$ & $2 \mathrm{~h}$ & $6 \mathrm{~h}$ & 0,70 & $\star \star$ & $\star$ & $\star$ \\
\hline KIM-1 dans l'urine & $\star$ & $\star \star \star \star$ & $6 \mathrm{~h}$ & $24 \mathrm{~h}$ & 0,68 & $\star \star$ & $\star$ & $\star$ \\
\hline $\begin{array}{l}\text { IGFBP7• TIMP-2 } \\
\text { dans l'urine }\end{array}$ & $\star$ & $\star \star \star \star$ & $1 \mathrm{~h}$ & $6 \mathrm{~h}$ & 0,75 & $\star \star$ & $\star \star \star$ & $\star \star$ \\
\hline Dialyse & $\star \star \star \star$ & $\star \star$ & $36 \mathrm{~h}$ & NA & 1,00 & $\star \star \star \star$ & $\star \star \star \star \star$ & $\star \star \star \star \star \star ~$ \\
\hline MAKE 30 & $\star \star \star \star$ & $\star \star$ & 30 jours & NA & NA & $\star \star \star$ & $\star \star \star \star$ & $\star \star \star \star$ \\
\hline МАКЕ 90 & $\star \star \star \star \star$ & $\star \star$ & 90 jours & NA & NA & $\star \star \star \star \star$ & $\star \star \star \star \star$ & $\star \star \star \star \star$ \\
\hline
\end{tabular}

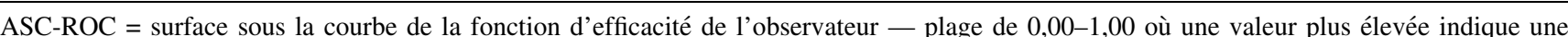
association supérieure avec les critères KDIGO pour l'IRA; KDIGO = amélioration des pronostics globaux des maladies rénales (Kidney Disease Improving Global Outcomes); NGAL = gélatinase de neutrophile associée à la lipocaline (neutrophil gelatinase-associated lipocalin); KIM-1 = molécule de lésion rénale 1 (kidney injury molecule 1); IGFBP7 = protéine de liaison au facteur de croissance insulinomimétique 7 (insulin-like growth factor binding protein 7); TIMP-2 = inhibiteur tissulaire de la métalloprotéinease 2 (tissue inhibitor of metalloproteinase 2); MAKE = événements rénaux indésirables importants (major adverse kidney events), un critère dichotomique à 30 ou 90 jours défini comme un taux de filtration glomérulaire estimé à $25 \%$, une nouvelle dialyse, ou le décès.

glomérulaire altérée (tableau 2). ${ }^{6,7}$ Leur utilisation clinique pour le diagnostic et la prise en charge de l'IRA demeure cependant limitée. En fait, la plupart de ces marqueurs ne sont utilisés qu'à des fins de recherche. La Food and Drug Administration des États-Unis a approuvé la mesure de l'inhibiteur des tissus urinaires de la métalloprotéase 2 et de la protéine de liaison au facteur de croissance insulinomimétique 7 (TIMP-2. IGFBP7), des marqueurs de l'arrêt des phases de croissance du cycle cellulaire, pour aider à évaluer les risques d'IRA modérée ou grave dans les 12 heures suivant une chirurgie cardiaque, fournissant ainsi un test disponible dans le commerce pour mesurer le stress rénal. La validation des biomarqueurs TIMP-2 et IGFBP7 pour les lésions rénales aiguës et persistantes dans différents contextes cliniques est en cours.

\section{Prévention de l'IRA}

La gestion liquidienne intravasculaire demeure primordiale dans la prévention de l'IRA. Jusqu'à récemment, la composition optimale de liquide isotonique est restée floue. Chez les patients en état critique, une solution saline équilibrée se rapprochant des concentrations plasmatiques de sodium, de chlorure et de potassium, telle que bon nombre des solutions électrolytiques disponibles dans le commerce, la solution de Hartmann ou le lactate de Ringer, a été associée à moins d'événements rénaux indésirables importants à 30 jours par rapport aux solutions hyperchlorémiques telles que la solution physiologique 'normal salin' $(0,9 \%){ }^{8}$ En outre, des données probantes récentes suggèrent que des solutions salines isotoniques équilibrées pourraient protéger les reins comparativement au chlorure de sodium isotonique. L'étude SMART, une étude randomisée de grande envergure évaluant une solution saline équilibrée ou un traitement normal salin administré immédiatement après l'admission à l'USI, a révélé qu'une solution saline équilibrée réduisait les événements rénaux indésirables importants à 30 jours par rapport au normal salin. ${ }^{9}$ Par conséquent, hormis certaines populations de patients tels que ceux présentant une pression intracrânienne augmentée, une solution saline équilibrée pourrait constituer un traitement préférable chez les patients en état critique. Malgré le peu de données probantes, les protocoles de récupération favorisant une administration restrictive de fluides intraveineux dans le but de faire progresser la récupération précoce des patients subissant une chirurgie majeure sont devenus populaires. Cependant, l'étude RELIEF a randomisé 3000 patients de chirurgie abdominale majeure à une administration liquidienne restrictive (environ 1,5 L de solution cristalline équilibrée au cours d'une chirurgie de quatre heures, suivis de 0,8 $\mathrm{mL} \cdot \mathrm{kg}^{-1} \cdot \mathrm{h}^{-1}$ pendant au moins 24 heures en période 
postopératoire) ou libérale (environ $3 \mathrm{~L}$ de cristalloïdes équilibrés au cours d'une chirurgie de quatre heures, suivis de $1,5 \mathrm{~mL} \cdot \mathrm{kg}^{-1} \cdot \mathrm{h}^{-1}$ pendant au moins 24 heures en période postopératoire) pendant la chirurgie et au cours de la période postopératoire précoce, et a constaté qu'une administration liquidienne restrictive n'était pas associée à une survie sans incapacité. ${ }^{10}$ En outre, les analyses secondaires pré-spécifiées ont noté une augmentation de l'IRA dans le groupe d'administration restrictive par rapport au groupe d'administration libérale. D'autres études randomisées contrôlées (ERC) pragmatiques d'envergure, y compris les études PLUS (NCT02721654), BaSICS (NCT02875873) et SOLAR (NCT02565420), fourniront des données probantes supplémentaires quant aux avantages et aux inconvénients rénaux relatifs des solutions cristalloïdes intraveineuses couramment administrées.

L'IRA associée au produit de contraste pourrait également être affectée par le choix de solution cristalloïde de réanimation. Par exemple, chez les patients recevant un produit de contraste par voie intraveineuse, l'administration d'un liquide isotonique intraveineux diminue l'IRA par rapport à un liquide hypotonique. En se fondant sur la prémisse selon laquelle le bicarbonate de sodium réduirait le stress oxydatif dans le néphron ou dans le sang en récupérant les ERO et en diminuant les ERO générées par des mécanismes dépendants du fer, les cliniciens-chercheurs ont émis l'hypothèse que l'administration de bicarbonate de sodium diminuerait l'IRA induite par les produits de contraste. Des études récentes chez des patients exposés aux produits de contraste n'ont toutefois trouvé aucune différence en matière de taux ou de gravité de l'IRA induite par les produits de contraste ou des lésions rénales persistantes entre les patients ayant reçu du bicarbonate de sodium isotonique et ceux ayant reçu du chlorure de sodium isotonique. ${ }^{11}$

Les solutions colloïdes ont fait l'objet de nombreuses recherches examinant leurs effets sur les lésions rénales et la récupération rénale. En se fondant sur le principe qu'une augmentation de la pression oncotique colloïde pourrait limiter l'extravasation liquidienne intravasculaire, des solutions d'amidon ont traditionnellement été administrées dans le cadre d'une réanimation du volume intravasculaire. On a observé que certaines solutions d'hydroxyéthylamidon augmentaient le risque d'IRA et de traitement substitutif de l'insuffisance rénale (TRR - thérapie de remplacement rénal) et entraînaient une augmentation de la mortalité chez les patients septiques. ${ }^{12}$ Les données concernant l'utilisation de l'albumine comme solution de réanimation ne sont pas concluantes. Dans d'importantes méta-analyses portant sur des patients septiques, la réanimation par l'albumine n'a eu aucun effet sur l'IRA ou le besoin de TRR. ${ }^{13}$ Dans une étude incluant des patients hypoalbuminémiques subissant une chirurgie de pontage aortocoronarien à cœur battant, l'administration d'albumine $20 \%$ en période préopératoire a augmenté la diurèse et diminué le risque d'IRA. ${ }^{14}$ L'administration d'albumine est plus coûteuse que l'administration de solutions cristalloïdes, et les résultats des études examinant les effets de l'albumine sur l'IRA sont mitigés. Il peut y avoir un certain avantage à son administration chez les patients hypoalbuminémiques, mais les données probantes sont insuffisantes pour soutenir une utilisation répandue de l'albumine comme liquide de réanimation pour prévenir une IRA.

L'anémie peut diminuer l'apport d'oxygène aux reins, et une concentration d'hémoglobine inférieure à $8 \mathrm{~g} \cdot \mathrm{dL}^{-1}(5$ $\mathrm{mmol} \cdot \mathrm{L}^{-1}$ ) pendant une chirurgie non cardiaque est associée à une augmentation de $400 \%$ de l'IRA. ${ }^{15} \mathrm{La}$ transfusion de culots sanguins a toutefois également été associée à l'IRA. ${ }^{16}$ L'étude TRICS III a randomisé 4860 patients de chirurgie cardiaque à un seuil de transfusion de $9,5 \mathrm{~g} \cdot \mathrm{dL}^{-1}$ ou $7,5 \mathrm{~g} \cdot \mathrm{dL}^{-1}$. Le seuil de transfusion n'a pas modifié de nouvelles insuffisances rénales exigeant une dialyse, malgré une augmentation des transfusions dans le groupe au seuil plus élevé, et une sous-étude rénale de cette étude n'a noté aucune différence dans l'IRA légère, modérée, ou grave entre les groupes de traitement randomisés. ${ }^{17}$ La transfusion de culots sanguins entreposés plus longtemps avant la transfusion augmente également le risque d'IRA. Les mécanismes putatifs incluent une augmentation de l'inflammation, du stress oxydatif, ou une diminution du transport de l'oxygène. Les recommandations actuelles mettent l'accent sur la prévention de l'anémie et une transfusion judicieuse de produits sanguins chez les patients chirurgicaux à risque d'IRA afin d'équilibrer les risques d'anémie et de transfusion.

La prise en charge préventive de l'IRA consiste également à maintenir la perfusion rénale et à éviter les médicaments réduisant la filtration glomérulaire chez les patients hypovolémiques, tels que les anti-inflammatoires non stéroïdiens et les inhibiteurs de l'enzyme de conversion de l'angiotensine, ainsi que d'éviter les néphrotoxines, y compris les produits de contraste intraveineux et les aminosides. L'identification des patients hypovolémiques et la quantification du degré de déplétion intravasculaire demeurent des problèmes cliniques importants, tout particulièrement étant donné que la réanimation excessive et l'hypervolémie mènent à la congestion veineuse, une condition liée à l'IRA dans les cohortes de patients subissant une chirurgie, souffrant de sepsis, admis à l'USI, ou souffrant d'insuffisance cardiaque. ${ }^{18}$ Les cliniciens ne peuvent plus se dire qu'ils protègent les reins en administrant de grandes quantités de 
liquides intraveineux. Les cliniciens devraient maintenir la perfusion rénale en préservant ou en augmentant le débit cardiaque, en traitant l'hypotension à l'aide d'agents qui augmentent également le débit cardiaque ou de liquides intraveineux tout en évitant l'hypervolémie, et en évitant l'anémie grave. Les agents vasoactifs qui augmentent exclusivement la résistance vasculaire systémique, comme la phényléphrine, pourraient ne pas être le meilleur choix pour préserver la perfusion rénale tout en traitant l'hypotension. Toutefois, dans une ERC portant sur des patients ayant subi un choc vasoplégique après une chirurgie cardiaque et recevant de la norépinéphrine, les patients traités à l'aide de vasopressine étaient moins susceptibles de manifester un résultat composite de mortalité ou de dysfonctionnement des organes comparativement aux patients traités avec de la noradrénaline supplémentaire. Les patients traités avec de la vasopressine ont affiché un rapport de risque de 0,26 en matière d'insuffisance rénale par rapport aux patients traités par norépinéphrine seulement, et des études supplémentaires examinant la vasopressine devraient être réalisées. ${ }^{19}$

Même si l'ischémie rénale est responsable d'une importante proportion des IRA périopératoires, les traitements pour augmenter la perfusion rénale ou diminuer la consommation d'oxygène rénal, y compris l'administration d'agonistes des récepteurs de la dopamine ou de diurétiques, ont largement échoué. Les agonistes de la dopamine augmentent la perfusion rénale, la filtration glomérulaire, l'apport de sodium au tubule, les besoins de réabsorption de soluté, et la consommation d'oxygène du tubule rénal. Les diurétiques diminuent la consommation d'oxygène rénal mais peuvent mener à l'hypovolémie et ne diminuent pas l'IRA. D'autres traitements préventifs, y compris l'administration périopératoire de statines chez les patients de chirurgie cardiaque, le bicarbonate de sodium, ${ }^{20}$ les corticostéroïdes ${ }^{21}$ et la phosphatase alcaline, ont donné des résultats mitigés, mais n'ont généralement pas réussi à réduire l'IRA. De même, plusieurs études cliniques examinant l'administration périopératoire d'antioxydants tels que la $\mathrm{N}$-acétyl-cystéine ou le mannitol n'appuient pas leur administration systématique pour prévenir une IRA. Le préconditionnement ischémique à distance est réalisé en gonflant un brassard sur un membre (le plus souvent le bras) à une pression suprasystolique pendant trois cycles de cinq minutes. Chez les patients de chirurgie cardiaque, deux grandes ERC ont constaté que le préconditionnement ischémique à distance ne diminuait pas le risque d'IRA, alors qu'une autre a observé un effet protecteur contre l'IRA.

\section{Progression, prise en charge et pronostic de l'insuffisance rénale aiguë}

Jusqu'à ce que des traitements spécifiques soient disponibles, le traitement de l'IRA doit se concentrer sur des soins de soutien et éviter de provoquer d'autres lésions. Bien que de nombreux facteurs de risque modifiables tels que l'anémie, l'hypotension, un débit cardiaque altéré, l'hémolyse, la rhabdomyolyse, l'exposition aux médicaments néphrotoxiques et la transfusion sanguine aient été identifiés, la plupart des stratégies thérapeutiques de prévention (et de sauvetage) pharmacologique n'ont pas réussi à renverser l'IRA chirurgicale ou à limiter sa progression. ${ }^{22}$ La prise en charge hémodynamique axée sur son optimisation constitue une approche raisonnable puisqu'elle utilise un monitorage et des interventions suivant un protocole avec des cibles hémodynamiques prédéfinies. D'une manière générale, cette stratégie de prise en charge des patients n'a pas réussi à limiter l'IRA de façon constante, bien qu'une étude menée auprès de patients de chirurgie cardiaque ait montré que l'optimisation du volume d'éjection - obtenue en monitorant les effets de tests de remplissage vasculaire de $250 \mathrm{~mL}$ sur le volume d'éjection ventriculaire gauche réduisait l'incidence d'IRA de $19,9 \%$ à $6,5 \%(P=$ 0,002). ${ }^{23}$

L'acidose, les perturbations électrolytiques, la surcharge de volume intravasculaire et l'urémie sévère indiquent généralement l'apparition d'une IRA qui nécessitera une TRR. Nous ne savons pas si l'amorce précoce ou tardive de la TRR neutralise la maladie critique, améliore la survie ou améliore la fonction rénale à long terme. Trois études cliniques randomisées récentes ont abordé cette question. Zarbock et coll. rapportent des données probantes selon lesquelles une amorce de la TRR dans les huit heures suivant une IRA de stade 2 réduit la mortalité à 90 jours, la durée de la TRR, la durée de la ventilation mécanique, et la durée de l'hospitalisation, tout en augmentant la récupération de la fonction rénale par rapport à une amorce de TRR dans les 12 heures d'une IRA de stade 3 chez 231 patients en état critique (étude ELAIN). ${ }^{24} \mathrm{Au}$ suivi à un an, une diminution des événements rénaux indésirables importants et de la mortalité ainsi qu'une récupération rénale améliorée ont persisté chez les patients de l'étude ELAIN ayant reçu une TRR précoce. Gaudry et coll. ont quant à eux constaté que les patients présentant une IRA de stade 3 et auxquels une TRR immédiate avaient été administrée présentaient une mortalité à 60 jours semblable aux patients ayant reçu une TRR après l'apparition de séquelles significatives d'insuffisance rénale; en outre, les patients du premier groupe ont subi davantage d'infections de la circulation sanguine liées aux cathéters et une récupération retardée de la fonction rénale 
(étude AKIKI). ${ }^{25}$ Barbar et coll. ont randomisé 488 patients présentant un choc septique et une insuffisance rénale de stade précoce, définis selon les critères RIFLE, à recevoir une TRR 12 heures après une insuffisance rénale documentée ou 48 heures si le rétablissement rénal n'avait pas eu lieu (étude IDEAL-ICU). ${ }^{26}$ Cette étude a été interrompue pour cause de futilité, aucune différence significative dans le critère d'évaluation principal de décès à 90 jours n'ayant été observée entre les groupes. Fait important, l'étude ELAIN incluait principalement des patients chirurgicaux présentant une prévalence élevée de surcharge liquidienne, tandis que les études AKIKI et IDEAL-ICU incluaient principalement des patients médicaux présentant une prévalence élevée de sepsis. Peut-être que l'amorce de la TRR alors que les patients étaient encore en IRA modérée a mené à un avantage du traitement précoce de TRR dans l'étude ELAIN. L'étude STARRT-AKI (NCT02568722) vise à recruter et randomiser 2866 patients atteints d'IRA de stade 2 ou présentant certains critères cliniques spécifiques à recevoir une TRR précoce ou tardive et fournira plus de données probantes. À l'heure actuelle, nous ne savons donc pas si l'amorce d'une TRR chez les patients présentant une IRA modérée sauvera les reins plutôt que d'attendre jusqu'à ce que les patients récupèrent ou que l'IRA s'aggrave.

Le test de stress au furosémide consiste en l'administration de furosémide à un patient qui souffre d'oligurie ou d'IRA pour mieux prévoir la progression de l'IRA et le besoin d'une TRR ultérieure. Ce test est basé sur une étude qui a démontré que le volume de diurèse après une dose de $1-1,5 \mathrm{mg} \cdot \mathrm{kg}^{-1}$ de furosémide intraveineux produisait une statistique $\mathrm{C}$ de 0,82 et 0,87 pour prédire l'évolution de l'IRA en stade 3 dans deux cohortes de patients atteints d'IRA de stade 1 ou $2 .{ }^{27}$ Une diurèse inférieure à $200 \mathrm{~mL}$ dans les deux heures suivant l'administration de furosémide a résulté en une sensibilité de $87,1 \%$ et une spécificité de $84,1 \%$ pour prédire la progression à une IRA de stade 3 . Les auteurs de cette étude mettent en garde que le volume de diurèse devrait être remplacé par des fluides intraveineux pendant un test de stress au furosémide, à moins que le patient ne manifeste une surcharge intravasculaire franche. En effet, de nombreuses études ont démontré que l'administration de furosémide afin de renverser l'oligurie ne réduisait pas mais augmentait l'IRA. Hormis dans le cadre d'un test de stress au furosémide, le furosémide devrait être réservé au traitement de l'hypervolémie intravasculaire.

La mortalité hospitalière chez les patients atteints d'IRA nécessitant une dialyse demeure importante à $30 \%{ }^{1}$ L'insuffisance rénale est fréquemment accompagnée d'insuffisance respiratoire, d'arythmies, d'insuffisance cardiovasculaire, d'infections graves, de polyneuropathie, de faiblesse musculaire et de delirium. ${ }^{28}$ Il y a de plus en plus de données probantes attestant que ces lésions d'organes ne se produisent pas simultanément en réponse à une insulte commune, mais que l'homéostasie liquidienne et électrolytique altérée, l'élimination réduite des déchets (acides fixes et urée), la production rénale de cytokines, la clairance réduite de cytokines, les voies de signalisation neuro-hormonales, ou une dégradation de l'activité des neutrophiles provoquent des effets délétères aux organes extra-rénaux. Par exemple, une ischémie-reperfusion rénale expérimentale préclinique précipite la margination des neutrophiles dans le rein controlatéral, la rate et les poumons, ${ }^{29}$ ainsi que l'infiltration de macrophages dans le poumon et l'interstitium myocardique, ${ }^{30}$ et provoque un œdème pulmonaire et cérébral. Ces effets extra-rénaux de l'IRA expérimentale pourraient expliquer les observations cliniques selon lesquelles même une IRA de stade 1 augmente le risque de dysfonctionnement d'organe extra-rénal et est associée à une augmentation par sept de la mortalité à 30 jours.

\section{Résolution de l'IRA — effets à court et à long terme}

Les reins peuvent récupérer d'une IRA. Après la perte de cellules tubulaires, les cellules survivantes, stimulées par la signalisation paracrine de cellules progénitrices dérivées de la moelle osseuse, se dédifférencient, prolifèrent, migrent le long de la membrane basale et se différencient en cellules tubulaires matures, réapprovisionnant l'épithélium tubulaire. ${ }^{3}$ Ce processus, cependant, est souvent inadapté. La gravité de l'IRA et des événements d'IRA répétitifs augmentent le risque de progression vers une insuffisance rénale chronique (IRC) (figure 1). Même si la fonction rénale récupère après une IRA, les patients qui subissent une IRA courent un risque accru de survenue d'épisodes ultérieurs d'IRA ou d'une aggravation d'une IRC.

L'insuffisance rénale aiguë est une complication fréquente, compliquée et éprouvante des maladies aiguës. Les patients récupèrent souvent d'une IRA mais souffrent ultérieurement de morbidité. Notre compréhension de la physiopathologie du développement de l'IRA s'est cependant améliorée, et des traitements empiriques ont récemment émergé. Les travaux futurs devront s'intéresser au traitement prophylactique de l'IRA et à la prolongation $\mathrm{du}$ monitorage et du traitement des patients après la résolution de l'IRA.

\section{Mise en situation clinique}

Mme Henle, une femme de 68 ans, se présente à l'urgence fiévreuse avec un pied gauche froid et oedématié. Elle a des antécédents d'hyperlipidémie et d'insuffisance cardiaque 
congestive. Sa fréquence cardiaque est de 93 battements•min ${ }^{-1}$ et sa tension artérielle de 95/50 $\mathrm{mmHg}$. Son pied gauche est marbré, et les pouls distaux sont diminués. Sa créatininémie est de $124 \mu \mathrm{mol} \cdot \mathrm{L}^{-1}(1,4$ $\left.\mathrm{mg} \cdot \mathrm{dL}^{-1}\right)$. Elle est amenée d'urgence pour passer une angiographie et subir une embolectomie sous sédation. On lui installe une sonde de Foley pour monitorer sa diurèse. Elle reçoit 1,5 L de solution intraveineuse de lactate de Ringer, plusieurs bolus de phényléphrine pour traiter son hypotension, et $125 \mathrm{~mL}$ de produit de contraste pendant la dilatation de l'artère poplitée gauche et l'implantation d'un stent endovasculaire. En salle de réveil, sa fréquence cardiaque est de 115 battements. $\min ^{-1}$ et sa tension artérielle de 82/42 $\mathrm{mmHg}$. Le potassium sérique est à 5,4 $\mathrm{mEq} \cdot \mathrm{L}^{-1}$. Elle est somnolente et anurique. Le médecin traitant demande un bolus intraveineux de $500 \mathrm{~mL}$ de solution physiologique $0,9 \%$, craignant que l'administration d'un soluté balancé contenant du potassium puisse aggraver son hyperkaliémie, et une perfusion de phényléphrine. Elle est transférée à l'unité de soins intensifs.

\section{Directives pour compléter le module de développement professionnel continu (DPC) :}

1. Lisez cet article et les quatre références en gras (références 1, 2, 22 et 28).

2. Aller à : http://www.cas.ca/Membres/modules-de-DPC et sélectionnez le module actuel (L'insuffisance rénale aiguë périopératoire : incidence, risques, présentation, physiopathologie, traitement et conséquences).

3. Répondez aux questions à choix multiples portant sur le cas clinique.

4. Une fois que vous aurez saisi toutes vos réponses, vous aurez accès aux explications d'experts pour tous les choix possibles.

5. Les participants peuvent déclarer jusqu'à quatre heures de DPC en vertu de la section 3 du Programme de DPC du Collège royal des médecins et chirurgiens du Canada.

\section{Disclosures None.}

Funding statement Support was provided by the United States National Institutes of Health (K23GM102676, K23GM129662, and R01GM112871) and the Vanderbilt University Department of Anesthesiology.

Editorial responsibility This submission was handled by Dr. Adriaan Van Rensburg, CPD Editor, Canadian Journal of Anesthesia.

Déclaration Aucune.
Déclaration de financement Un soutien a été fourni par les National Institutes of Health des États-Unis (K23GM102676, K23GM129662 et R01GM112871) et par le Département d'anesthésiologie de l'Université Vanderbilt.

Editorial responsibility Cet article a été traité par Dr Adriaan Van Rensburg, rédacteur des DPC, Journal canadien d'anesthésie.

\section{References}

1. Meersch $M$, Schmidt $C$, Zarbock A. Perioperative acute kidney injury: an under-recognized problem. Anesth Analg 2017; 125: $1223-32$.

2. Billings FT 4th, Pretorius $M$, Schildcrout JS, et al. Obesity and oxidative stress predict AKI after cardiac surgery. J Am Soc Nephrol 2012; 23: 1221-8.

3. Bonventre JV, Yang L. Cellular pathophysiology of ischemic acute kidney injury. J Clin Invest 2011; 121: 4210-21.

4. KDIGO AKI Work Group. KDIGO clinical practice guideline for acute kidney injury. Kidney Int Suppl 2012; 2: 1-138.

5. Kellum JA, Sileanu FE, Murugan R, Lucko $N$, Shaw AD, Clermont $G$. Classifying AKI by urine output versus serum creatinine level. J Am Soc Nephrol 2015; 26: 2231-8.

6. Han WK, Waikar SS, Johnson A, et al. Urinary biomarkers in the early diagnosis of acute kidney injury. Kidney Int 2008; 73: 863-9.

7. Kashani K, Al-Khafaji A, Ardiles $T$, et al. Discovery and validation of cell cycle arrest biomarkers in human acute kidney injury. Crit Care 2013. DOI: https://doi.org/10.1186/ cc12503.

8. Yunos NM, Bellomo R, Hegarty C, Story D, Ho L, Bailey M. Association between a chloride-liberal vs chloride-restrictive intravenous fluid administration strategy and kidney injury in critically ill adults. JAMA 2012; 308: 1566-72.

9. Semler $M W$, Self $W H$, Wanderer JP, et al. Balanced crystalloids versus saline in critically ill adults. N Engl J Med 2018; 378: 829-39.

10. Myles PS, Bellomo R, Corcoran T, et al. Restrictive versus liberal fluid therapy for major abdominal surgery. N Engl J Med 2018; 378: 2263-74.

11. Weisbord SD, Gallagher M, Jneid H, et al. Outcomes after angiography with sodium bicarbonate and acetylcysteine. N Engl J Med 2018; 378: 603-14.

12. Perner A, Haase N, Guttormsen AB, et al. Hydroxyethyl starch 130/0.42 versus Ringer's acetate in severe sepsis. N Engl J Med 2012; 367: 124-34.

13. Wiedermann CJ, Dunzendorfer $S$, Gaioni LU, Zaraca F, Joannidis $M$. Hyperoncotic colloids and acute kidney injury: a meta-analysis of randomized trials. Crit Care 2010. DOI: https:// doi.org/10.1186/cc9308.

14. Lee EH, Kim WJ, Kim JY, et al. Effect of exogenous albumin on the incidence of postoperative acute kidney injury in patients undergoing off-pump coronary artery bypass surgery with a preoperative albumin level of less than $4.0 \mathrm{~g} / \mathrm{dl}$. Anesthesiology 2016; 124: 1001-11.

15. Walsh M, Garg AX, Devereaux PJ, Argalious M, Honar H, Sessler DI. The association between perioperative hemoglobin and acute kidney injury in patients having noncardiac surgery. Anesth Analg 2013; 117: 924-31.

16. Marik PE, Corwin HL. Efficacy of red blood cell transfusion in the critically ill: a systematic review of the literature. Crit Care Med 2008; 36: 2667-74. 
17. Mazer CD, Whitlock RP, Fergusson DA, et al. Restrictive or liberal red-cell transfusion for cardiac surgery. N Engl J Med 2017; 377: 2133-44.

18. Chen KP, Cavender S, Lee J, et al. Peripheral edema, central venous pressure, and risk of AKI in critical illness. Clin J Am Soc Nephrol 2016; 11: 602-8.

19. Hajjar LA, Vincent JL, Barbosa Gomes Galas FR, et al. Vasopressin versus norepinephrine in patients with vasoplegic shock after cardiac surgery: the VANCS randomized controlled trial. Anesthesiology 2017; 126: 85-93.

20. McGuinness SP, Parke RL, Bellomo R, Van Haren FM, Bailey M. Sodium bicarbonate infusion to reduce cardiac surgery-associated acute kidney injury: a phase II multicenter double-blind randomized controlled trial. Crit Care Med 2013; 41: 1599-607.

21. Whitlock RP, Devereaux PJ, Teoh KH, et al. Methylprednisolone in patients undergoing cardiopulmonary bypass (SIRS): a randomised, double-blind, placebo-controlled trial. Lancet 2015; 386: 1243-53.

22. Joannidis $M$, Druml W, Forni LG, et al. Prevention of acute kidney injury and protection of renal function in the intensive care unit: update 2017: expert opinion of the Working Group on Prevention, AKI section, European Society of Intensive Care Medicine. Intensive Care Med 2017; 43: 730-49.

23. Thomson R, Meeran H, Valencia O, Al-Subaie N. Goal-directed therapy after cardiac surgery and the incidence of acute kidney injury. J Crit Care 2014; 29: 997-1000.

24. Zarbock A, Kellum JA, Schmidt C, et al. Effect of early vs delayed initiation of renal replacement therapy on mortality in critically ill patients with acute kidney injury: the ELAIN randomized clinical trial. JAMA 2016; 315: 2190-9.

25. Gaudry S, Hajage D, Schortgen $F$, et al. Initiation strategies for renal-replacement therapy in the intensive care unit. $\mathrm{N}$ Engl $\mathrm{J}$ Med 2016; 375: 122-33.

26. Barbar SD, Clere-Jehl R, Bourredjem A, et al. Timing of renalreplacement therapy in patients with acute kidney injury and sepsis. N Engl J Med 2018; 379: 1431-42.

27. Chawla LS, Davison DL, Brasha-Mitchell E, et al. Development and standardization of a furosemide stress test to predict the severity of acute kidney injury. Crit Care 2013. DOI: https://doi. org/10.1186/cc13015.

28. Doyle JF, Forni LG. Acute kidney injury: short-term and longterm effects. Crit Care 2016. DOI: https://doi.org/10.1186/ s13054-016-1353-y.

29. Awad AS, Rouse M, Huang L, et al. Compartmentalization of neutrophils in the kidney and lung following acute ischemic kidney injury. Kidney Int 2009; 75: 689-98.

30. Tokuyama H, Kelly DJ, Zhang Y, Gow RM, Gilbert RE. Macrophage infiltration and cellular proliferation in the nonischemic kidney and heart following prolonged unilateral renal ischemia. Nephron Physiol 2007; 106: 54-62.

Publisher's Note Springer Nature remains neutral with regard to jurisdictional claims in published maps and institutional affiliations. 